\title{
Preculture Conditions Influence Cold Hardiness and Regrowth of Pyrus cordata Shoot Tips After Cryopreservation
}

\author{
Yongjian Chang \\ Department of Horticulture, Oregon State University, Corvallis, OR 97331 \\ Barbara M. Reed ${ }^{1}$ \\ United States Department of Agriculture, Agricultural Research Service, National \\ Clonal Germplasm Repository, 33447 Peoria Road, Corvallis, OR 97333
}

Additional index words. ABA, cryopreservation, freezing tolerance, pear, shoot tip, sucrose

\begin{abstract}
Cold hardiness and cryogenic survival of micropropagated pear (Pyrus cordata Desv.) shoots were evaluated after pretreatments with ABA and sucrose. Shoot cold hardiness increased by $3{ }^{\circ} \mathrm{C}$, and cryopreserved shoot tip growth increased by $17 \%$ after a 4-week $150 \mu_{\mathrm{M}} \mathrm{ABA}$ pretreatment. Low temperature (LT) pretreatments improved the recovery of cryopreserved $P$. cordata shoot tips. Six to 10 weeks of $L T$ were required for reaching high cryopreservation recovery. ABA and LT treatments produced significant synergistic effects on both cold hardiness and cryopreservation recovery. ABA shortened the $L T$ requirement for high cryopreservation growth from 10 to 2 weeks. The optimal treatment for recovery of cryopreserved shoot tips was a 3 week culture on $50 \mu \mathrm{M}$ ABA followed by 2 weeks of $L T$, while the maximum cold hardiness $\left(-22.5^{\circ} \mathrm{C}\right)$ was obtained with $150 \mu_{\mathrm{M}} \mathrm{ABA}$ and 2-week LT. A 4 week culture on $150 \mu_{\mathrm{M} \mathrm{ABA}} \mathrm{At} 25^{\circ} \mathrm{C}$ induced dormancy in $74 \%$ of shoot tips, but had little effect on cryopreservation growth unless combined with LT. Control and ABA-treated shoot tips, lateral buds, and leaves had similar cold hardiness $\left(-10\right.$ to $\left.-12{ }^{\circ} \mathrm{C}\right)$, but $\mathrm{LT}$ and LT+ABA-treated shoot tips survived the lowest temperatures $\left(-17\right.$ to $\left.-23^{\circ} \mathrm{C}\right)$, lateral buds next $\left(-15\right.$ to $\left.-20{ }^{\circ} \mathrm{C}\right)$, and finally leaves $(-14$ to $\left.-18{ }^{\circ} \mathrm{C}\right)$. An increase in the preculture-medium sucrose concentration from $2 \%$ to $7 \%$ combined with 2-week LT significantly increased cryopreserved shoot tip growth $(0 \%$ to $75 \%$ ) and decreased the $\mathrm{LT}_{50}$ from -7.8 to $-12.4{ }^{\circ} \mathrm{C}$. The optimal shoot pretreatment for successful recovery of cryopreserved $P$. cordata shoot tips was a 3 week culture on either $50 \mu \mathrm{M}$ ABA or $5 \%$ to $7 \%$ sucrose medium followed by 2 weeks of LT, and increased shoot tip growth from zero to $>70 \%$. Chemical name used: abscisic acid (ABA).
\end{abstract}

Cryopreservation for germplasm storage is increasingly important for national germplasm collections (Withers, 1991). Clonally propagated crops such as fruit, nut, and many root and tuber vegetables cannot be stored as seed and are especially suited for cryopreserved storage. Pear germplasm is now stored in the cryopreserved form as base storage for the active field collections of the U.S. National Plant Germplasm System (Reed et al., 1998b). Cryopreservation techniques that are effective for a wide range of genotypes are important for both genebanks and breeder's collections.

Many techniques are used to prepare plant materials for cryopreserved storage, including osmotic and temperature conditioning and chemical additives at various stages of the cryopreservation process (Reed and Chang, 1997). Osmotic conditioning with sugars is often used for cryopreservation. Natural

Received for publication 12 Oct. 2000. Accepted for publication 16 Mar. 2001. Use of trade names in this publication does not imply endorsement of the U.S. Dept. of Agriculture (USDA) or Oregon State Univ. ${ }^{1}$ To whom requests for reprints should be addressed. E-mail address: reedbm@bcc.orst.edu sucrose, an important chemical in dehydration and freezing tolerance, is a commonly used cryoprotectant (Dumet et al., 1993; Niino et al., 1992). Sucrose cryoprotectant solutions are highly concentrated (10\% to $50 \%)$ and applied for short duration (16 h to several days). High sucrose concentration in the medium of in vitro-grown apples and blackberries significantly increases tissue freeze tolerance (Caswell et al., 1986; Palonen and Junttila, 1999).

ABA is an important stress hormone produced during cold acclimation. Chen et al. (1983) suggest that increased ABA concentrations in cells trigger cold acclimation and expression of low temperature-responsive genes. ABA increases the cold hardiness of cell cultures and whole plants of many species (Chen and Gusta, 1983; Lang et al., 1989; Tanino et al., 1990a; Veisz et al., 1996). Exposing tissues to ABA at room temperature substitutes for low temperature (LT) treatments for cold acclimating embryogenic wheat callus and the resulting lethal temperature at which $50 \%$ of cultures die $\left(\mathrm{LT}_{50}\right)$ is similar for callus treated with $\mathrm{ABA}$ and LT acclimation. ABA has a much weaker effect on intact wheat than on wheat callus (Dallaire et al., 1994). ABA in the preculture medium improves the recovery of cryopreserved shoot tips of several plant species (Pence, 1998; Reed, 1993; Ryynanen, 1998; Vandenbussche and De Proft, 1998).

LT pretreatments increase cold acclimation and improve the recovery of cryopreserved in vitro-grown shoot tips. However, some plant species require long LT treatments, some genotypes do not respond to LT, and others do not tolerate LT (Chang and Reed, 1997). Cold acclimation is essential for shoot tip cryopreservation of most pear genotypes (Reed et al., 1998a). The relationship of ABA, cold hardiness, and cryopreservation of in vitro-grown pear has not been studied.

Our objectives were to determine the effects of pretreatments of LT, ABA, and sucrose on the cold hardiness of pear shoots and on cryopreserved shoot tip recovery, and to examine the interactions between $\mathrm{ABA}$ and LT for inducing cold acclimation and improving recovery from cryopreservation.

\section{Materials and Methods}

Plant materials. Pyrus cordata (accession PYR 750.001) was selected because of its poor response to standard cryopreservation protocols in earlier studies (Chang and Reed, 2000). Micropropagated shoots of $P$. cordata were cultured in Magenta GA7 boxes (Magenta Corp., Chicago) on $40 \mathrm{~mL}$ of Cheng medium (Cheng, 1979), with $4.9 \mu \mathrm{M} \mathrm{N}^{6}-$ benzyladenine (BA), 3\% sucrose, $0.35 \%$ agar (Bitek agar, Difco, Detroit) and $0.145 \%$ Gelrite (Kelco, San Diego, Calif.). The pH was adjusted to 5.2 before autoclaving. Growth room conditions were $25^{\circ} \mathrm{C}$ with a 16-h photoperiod $\left(25 \mu \mathrm{mol} \cdot \mathrm{m}^{-2} \cdot \mathrm{s}^{-1}\right)$ and $40 \%$ relative humidity $(\mathrm{RH})$. Shoots were transferred at 3 week intervals. Shoots were LT acclimated in a growth chamber at $22^{\circ} \mathrm{C}$ with 8-h light $\left(10 \mu \mathrm{mol} \cdot \mathrm{m}^{-2} \cdot \mathrm{s}^{-1}\right)$ and $-1{ }^{\circ} \mathrm{C} 16$-h darkness (Reed, 1990).

ABA treatments. Shoots were cultured for 3 weeks on the medium described above with $0,10,25,50,75,100$, and $150 \mu \mathrm{M}( \pm)$ cistrans-abscisic acid (Sigma Chemical Co., St. Louis). After 3 weeks, the shoots were placed in the LT chamber for 0,1 , or 2 weeks without transfer to new medium. Cold hardiness and the cryogenic recovery of the shoots were tested at the end of the LT treatment. To determine the effect of $\mathrm{ABA}$ on growth, we dissected apical shoot tips $(1.0 \mathrm{~mm})$ from shoots grown for 3 weeks on each ABA concentration and transferred them to regular medium. Growth data were recorded at 4 weeks. If the shoot tips remained green but did not grow new shoots or leaves by 4 weeks, they were considered dormant.

Sucrose and BA treatments. Shoots of $P$. cordata were cultured on medium with $2 \%$, $3 \%, 5 \%$, or $7 \%$ sucrose and $0.89,2.22$, or 4.44 $\mu \mathrm{M}$ BA for 3 weeks and then placed in the LT chamber for 0,1 , or 2 weeks without transfer to new medium.

Freezing procedure. After ABA, sucrose, BA, or LT pretreatment, 25 shoot tips $(0.8-$ 
$1.0 \mathrm{~mm}$ ) of each treatment were dissected and precultured on medium with $0.35 \%$ agar, $0.18 \%$ Gelrite, and 5\% dimethyl sulfoxide (DMSO) for $48 \mathrm{~h}$ under the same temperature conditions as the parent shoots. Samples were subjected to slow freezing (Reed, 1990). Shoot tips were transferred to $0.25 \mathrm{~mL}$ liquid medium in $1.2 \mathrm{~mL}$ plastic cryo-vials (Cryovial, Beloeil, Quebec, Canada) on ice. The cryoprotectant PGD (Finkle and Ulrich, 1979), a mixture of $10 \%$ (w/w) each of polyethylene glycol (MW 8000), glucose, and DMSO in liquid medium was added dropwise up to $1.2 \mathrm{~mL}$ over $30 \mathrm{~min}$. After $30 \mathrm{~min}$ equilibration on ice, the shoot tips were frozen to $-40{ }^{\circ} \mathrm{C}$ at $0.1{ }^{\circ} \mathrm{C} / \mathrm{min}$ in a programmable freezer (Cryomed, Forma Scientific, Mt. Clemens, Mich.) with nucleation at $-9^{\circ} \mathrm{C}$ and immersed in liquid nitrogen for at least $1 \mathrm{~h}$. Vials were thawed in $45^{\circ} \mathrm{C}$ water for $1 \mathrm{~min}$, then in $23{ }^{\circ} \mathrm{C}$ water for $2 \mathrm{~min}$. The cryoprotectant was removed and replaced with liquid Cheng medium. Shoot tips were plated in 24-cell plates with $2 \mathrm{~mL}$ Cheng medium per cell (Costar, Cambridge, Mass.) for recovery. Growth data were taken 4 weeks after thawing. Each experiment comprised 20 shoot tips in one vial for each treatment and five shoot tips for unfrozen controls, with at least three replications per experiment.

Cold hardiness test. Ten shoots were enclosed in a piece $(11.4 \times 11.5 \mathrm{~cm})$ of moist sterile tissue paper (Kimwipes, KimberlyClark Corp., Roswell, Ga.) in each test tube $(15 \times 100 \mathrm{~mm})$ and closed with a plastic cap sealed with parafilm. Tubes were cooled at $0.1^{\circ} \mathrm{C} / \mathrm{min}$ in a programmable freezer with automatic ice nucleation at $-2{ }^{\circ} \mathrm{C}$. Five tubes per treatment were removed at each $2.5^{\circ} \mathrm{C}$ interval. Shoots were thawed at $4{ }^{\circ} \mathrm{C}$ for $3 \mathrm{~h}$ and recultured on Cheng medium. Leaves that retained green color for 2 weeks were considered alive. Only shoot tips and buds that developed into plantlets were considered to have survived. Viability was expressed as $\mathrm{LT}_{50}$, the temperature at which $50 \%$ of the shoots were killed.

Fresh weight/dry weight. Shoot water content was determined as the difference between dry weight (DW) and fresh weight (FW). DWs were determined after heating the samples in an oven at $95^{\circ} \mathrm{C}$ for $24 \mathrm{~h}$. Percentage of water was calculated as: $[(\mathrm{FW}-\mathrm{DW}) / \mathrm{FW}] \times 100$.

Osmotic potential measurement. The water potential of the medium and the osmotic potential of $P$. cordata shoots at different culture or LT durations were measured on expressed sap using a vapor pressure osmometer (5100C; Wescor, Logan, Utah). The medium was frozen at $-20{ }^{\circ} \mathrm{C}$ for $16 \mathrm{~h}$, then thawed for $5 \mathrm{~min}$ at room temperature $\left(22^{\circ} \mathrm{C}\right)$. Aliquots of the medium $(0.5 \mathrm{~mL})$ were centrifuged in $1.5-\mathrm{mL}$ microfuge tubes (Fisher Scientific, Pittsburgh) at $3000 \mathrm{rpm}$ for $5 \mathrm{~min}$. Shoots were frozen in the microfuge tubes overnight, thawed for $3 \mathrm{~min}$ at room temperature, then pressed with a glass bar to extract the sap. Sap was centrifuged at $3000 \mathrm{rpm}$ for 5 min to obtain a clear supernatant (Guak, 1998). Osmolalities were converted to MPa by multiplying by 2.48 (According to Van't
Hoff's equation $\Psi=-\mathrm{RT} \Sigma \mathrm{Cj}$, where $\mathrm{R}$ is the gas constant, $\mathrm{T}$ was the temperature in degrees Kelvin and $\mathrm{Cj}$ was the summation of the concentrations of all solutes in the solution). There were at least three replications for each treatment.

Statistical analysis. The results were analyzed by analysis of variance (ANOVA) and means separated with Duncan's multiple range test $(P \leq 0.05)$ using Statgraphics Plus (Statistical Graphics Corp. and STSC Rockville, Md.).

\section{Results and Discussion}

$A B A$ and LT effects on the cold hardiness of centrations of ABA produced increasingly lower $\mathrm{LT}_{50} \mathrm{~s}$ either with or without $\mathrm{LT}$ treatments (Fig. 1). Shoots grown at $25{ }^{\circ} \mathrm{C}$ were the hardiest on $150 \mu \mathrm{M}$ ABA with an $\mathrm{LT}_{50}$ of $-12.5^{\circ} \mathrm{C}$. This was $2.5^{\circ} \mathrm{C}$ lower than the non-ABA controls. LT treatments produced greater increases in cold hardiness than the ABA treatments. Non-ABA control shoot $\mathrm{LT}_{50} \mathrm{~s}$ were $4{ }^{\circ} \mathrm{C}$ lower with 1 -week LT and $7^{\circ} \mathrm{C}$ lower with 2-week LT compared to the non-LT, non-ABA controls. ABA and LT interacted to improve plant cold hardiness. The addition of $150 \mu \mathrm{M} \mathrm{ABA}$ to the LT treatments reduced the $\mathrm{LT}_{50}$ to $-17.5^{\circ} \mathrm{C}$ after 1 week and to $-22.5^{\circ} \mathrm{C}$ after 2 weeks.

Effect of ABA and LT on cold hardiness of pear tissues. Lateral buds, leaves, and shoot tips of control shoots had $\mathrm{LT}_{50} \mathrm{~s}$ near $-10^{\circ} \mathrm{C}$ (Table 1). ABA $(75 \mu \mathrm{M})$ treatment significantly increased tissue cold hardiness, but by only 1 to $2{ }^{\circ} \mathrm{C}$, and there were no significant differences among the three tissues $(P \leq 0.05)$. LT treatments significantly increased shoot cold hardiness and the effect was significantly stronger than ABA treatment for all three tissues. Shoot tips had the greatest rein vitro-grown pear shoots. Increasing con-

sponse to LT and were significantly hardier than leaves and lateral buds $(P \leq 0.05)$. The combined ABA and LT treatment increased the hardiness of all three tissues with shoot tips and lateral buds both significantly hardier than leaves.

ABA $(75-150 \mu \mathrm{M})$ in the preculture medium increased the cold hardiness of $P$. cordata shoots by only a few degrees (Fig. 1) and only slightly improved cryopreservation recovery. LT induced much deeper cold hardiness than ABA. ABA did not substitute for LT for inducing cold hardiness. These responses indicate that $\mathrm{ABA}$ and $\mathrm{LT}$ induce cold hardiness by different pathways. A similar conclusion was reached in studies on wheat (Dallaire et al., 1994), where ABA $(50 \mu \mathrm{M})$ application increased the cold hardiness of intact wheat plants by $3{ }^{\circ} \mathrm{C}$, while LT induced much deeper cold hardiness. For five Rubus genotypes, although cold hardiness was not directly tested, LT combined with ABA $(50 \mu \mathrm{M})$ treatment of stock cultures improved the growth of cryopreserved shoot tips, while ABA alone had little effect (Reed, 1993). LT treatments improved cryopreservation recovery of $P$. cordata shoots from no growth of controls (no LT) to $>80 \%$ after 12 weeks of LT (Chang and Reed, 1997). Long periods of LT acclimation (2 to 12 weeks), are required to achieve maximum cold hardiness in many pear genotypes including $P$. calleryana Decne, $P$. koehnei Schneider, P. pashia Buch. -Ham. ex D. Don, and $P$. communis L. cvs. Beurre d'Amanlis Panachee, Bosc-OP-5, Monchallard, and Good Christian (Chang and Reed, 1997). In the current study, $P$. cordata shoot cold hardiness significantly improved when ABA and LT were applied together and less exposure to LT was required with the ABA treatment. This is similar to Rubus hybrid cv. Hillemeyer that has improved cryopreser-

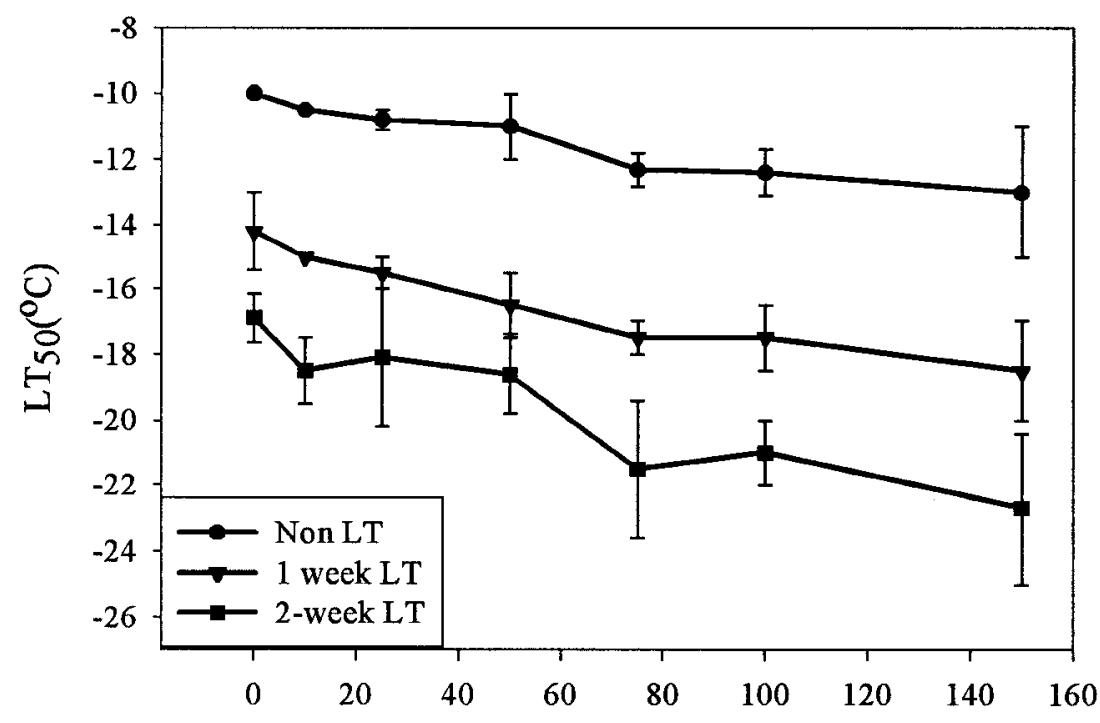

\section{ABA concentration $(\mu \mathrm{M})$}

Fig. 1. Cold hardiness of in vitro-grown $P$. cordata shoots determined by $\mathrm{LT}_{50}$ after 3 -week growth on Cheng medium with various ABA treatments followed by 0,1 , or 2 -week low temperature (LT) treatment $\left(22{ }^{\circ} \mathrm{C}\right.$ with 8 -h light $\left(10 \mu \mathrm{mol} \cdot \mathrm{m}^{-2} \cdot \mathrm{s}^{-1}\right)$ and $-1{ }^{\circ} \mathrm{C} 16$-h darkness $)$. Five replicates of 10 shoots each $(\mathrm{N}=50)$. 
vation growth with LT pretreatment (from $17 \%$ to $21 \%$ ), but growth more than doubles (52\%) with combined LT and ABA pretreatments (Reed, 1993). In $P$. cordata, pretreatment with ABA and 2 weeks of LT produced cold hardiness similar to that produced with 12 weeks of LT pretreatment (data not shown). Shoot tips appear to be best for cryopreservation not only because of their genetic stability, but also because they attain the deepest cold hardiness and withstand freezing.

Dormancy induction by $A B A$. ABA induced apical dormancy in shoot tips of $P$. cordata and the rate increased with increasing $\mathrm{ABA}$ concentrations. After 3 weeks of growth, $30 \%$ of shoot tips on $50-80 \mu \mathrm{M}, 50 \%$ on $100 \mu \mathrm{M}$, and $75 \%$ on medium with $150 \mu \mathrm{M}$ ABA formed dormant apical buds. ABA concentrations below $25 \mu \mathrm{M}$ did not affect shoot tip growth or induce dormancy.

Effects of $A B A$ and $L T$ pretreatments on the growth of cryopreserved pear shoot tips. ABA pretreatments alone slightly improved shoot tip growth (Fig. 2). Without LT, growth of shoot tips pretreated on $150 \mu \mathrm{M}$ ABA was $17 \%$ compared to zero for the control (no ABA or LT). LT treatments for 2 weeks (without $\mathrm{ABA}$ ) produced $\approx 20 \%$ shoot tip growth while control (no ABA or LT) and 1 week of LT shoot tips did not survive. ABA and LT treatments interacted to improve growth of cryopreserved shoot tips (Table 2). Shoots treated with $50 \mu \mathrm{M}$ ABA alone had $<10 \%$ shoot tip growth after thawing, but growth increased to $38 \%$ with only 1 week of LT and to over $70 \%$ with 2 weeks of LT. Increasing ABA to $75 \mu \mathrm{M}$ or $150 \mu \mathrm{M}$ slightly improved non-LT treated shoot tip growth (from $8 \%$ to $20 \%$ ), but shoots with 1 or 2 weeks of LT produced $40 \%$ to $50 \%$ shoot tip growth. Without ABA, extended LT treatments ( 10 week) are required for $>80 \%$ growth of cryopreserved $P$. cordata shoot tips and 6 to 8 weeks of LT for $>50 \%$ growth (Chang and Reed, 1997).

Dehydration tolerance of Medicago sativa L. and Brassica napus L. is increased by adding ABA to the culture medium (Anandarajah and McKersie, 1990; Senaratna et al., 1991). Dehydration and freezing tolerance are well correlated with improved growth of shoot tips following cryopreservation (Chang and Reed, 2000). In this study, ABA treatment slightly increased the shoot tip growth (Fig. 2) and decreased shoot water content (Fig. 3A). There are two suggested mechanisms by which ABA could confer freezing tolerance in plants: maintenance of a favorable water balance (Rikin et al., 1981; Tanino et al., 1990b) or induction of specific sets of genes that produce freeze-protective products (Lee et al., 1991). Without further analysis, it is difficult to say which mechanism is applicable to pear tissues.

Sucrose effects on shoot cold hardiness. Shoot cold hardiness increased significantly with increasing pretreatment-medium sucrose concentrations (Table 3). The $\mathrm{LT}_{50}$ of shoots grown on $7 \%$ sucrose with no-LT treatment was significantly lower $(P \leq 0.05)$ than those

Table 1. Cold hardiness of in vitro-grown $P$. cordata shoot tissues determined by $\mathrm{LT}_{50}$ following a 3-week growth on $75 \mu \mathrm{M} \mathrm{ABA}$, a 2-week LT pretreatment, or both.

\begin{tabular}{llllr}
\hline \hline & \multicolumn{4}{c}{$\mathrm{LT}_{50}\left({ }^{\circ} \mathrm{C}\right)$} \\
\cline { 2 - 5 } Type of tissues & Control $^{\mathrm{y}}$ & $+\mathrm{ABA}^{\mathrm{y}}$ & $+\mathrm{LT}^{\mathrm{x}}$ & $+\mathrm{ABA}+\mathrm{LT}^{\mathrm{w}}$ \\
\hline Shoot tips & $-10.8 \mathrm{aD}^{\mathrm{v}}$ & $-12.4 \mathrm{aC}$ & $-16.9 \mathrm{aB}$ & $-22.5 \mathrm{aA}$ \\
Lateral buds & $-11.1 \mathrm{aD}$ & $-12.5 \mathrm{aC}$ & $-15.2 \mathrm{bB}$ & $-20.1 \mathrm{bA}$ \\
Leaves & $-10.1 \mathrm{aD}$ & $-12.1 \mathrm{aC}$ & $-14.1 \mathrm{bB}$ & $-17.9 \mathrm{cA}$ \\
Means & $-10.7 \mathrm{D}$ & $-12.3 \mathrm{C}$ & $-15.4 \mathrm{~B}$ & $-20.2 \mathrm{~A}$ \\
\hline
\end{tabular}

${ }^{2}$ Control: 3 weeks of growth at $25^{\circ} \mathrm{C}$ with no ABA.

${ }^{y}+\mathrm{ABA}: 3$ weeks of growth at $25^{\circ} \mathrm{C}$ with $75 \mu \mathrm{M} \mathrm{ABA}$.

${ }^{x}+\mathrm{LT}: 2$ week $\mathrm{LT}$ at $22^{\circ} \mathrm{C}$ with $8 \mathrm{~h}$ light $\left(10 \mu \mathrm{mol} \cdot \mathrm{m}^{-2} \cdot \mathrm{s}^{-1}\right)$ and $-1{ }^{\circ} \mathrm{C} 16 \mathrm{~h}$ darkness.

${ }^{\mathrm{w}}+\mathrm{ABA}+\mathrm{LT}$ : Growth at $25^{\circ} \mathrm{C}$ for 3 weeks with $75 \mu \mathrm{M}$ ABA then a 2-week LT treatment.

${ }^{\circ}$ Means in a row with different capital letters (A-D) are significantly different at $P \leq 0.05$;

Means in a column with different lower case letters $(\mathrm{a}-\mathrm{c})$ are significantly different at $P \leq 0.05$.

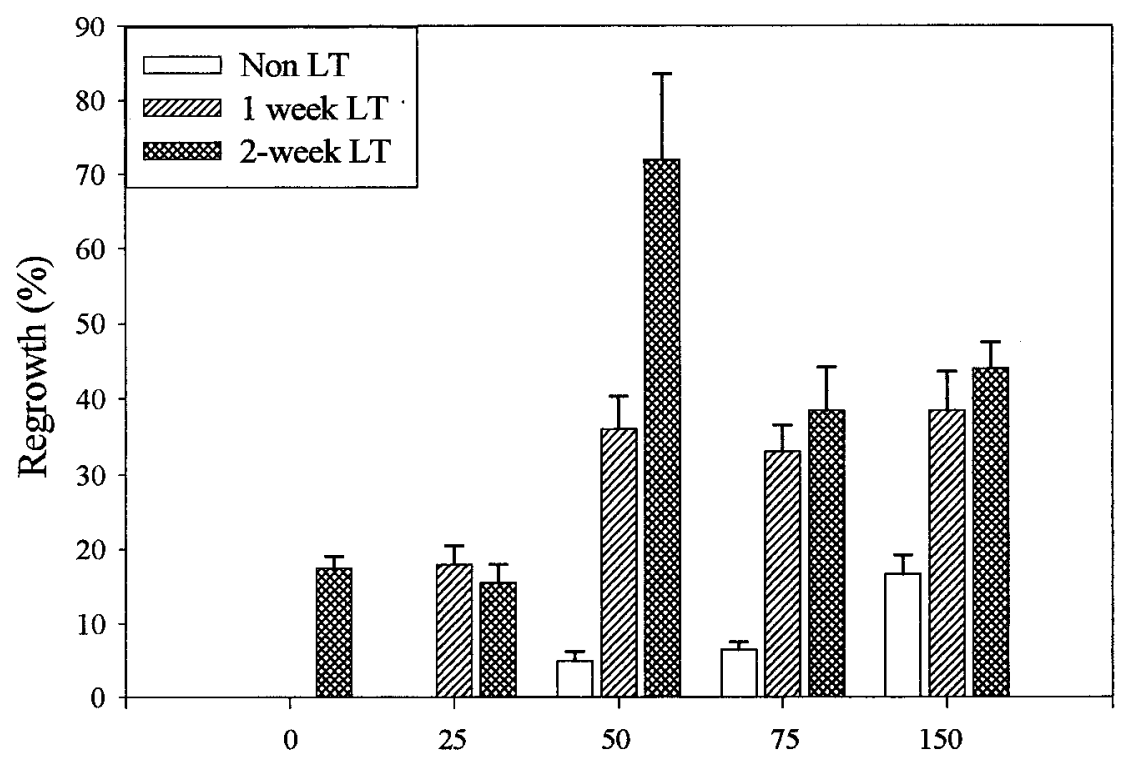

ABA concentration $(\mu \mathrm{M})$

Fig. 2. Growth of in vitro-grown $P$. cordata shoot tips after a 3 -week culture with various ABA treatments followed by 0,1 , or 2 week low temperature (LT) treatment $\left(22^{\circ} \mathrm{C}\right.$ with $8 \mathrm{~h}$ light $\left(10 \mu \mathrm{mol} \cdot \mathrm{m}^{-2} \cdot \mathrm{s}^{-1}\right)$ and $-1{ }^{\circ} \mathrm{C} 16 \mathrm{~h}$ darkness) on the same medium. $\mathrm{N}=60$; means $+\mathrm{SD}$.

Table 2. Analysis of variance for frequency of recovery of in vitro-grown $P$. cordata shoot tips after 3 weeks of growth with $0.75 \mu \mathrm{M} A B A$ followed by 0,1 , or 2 weeks of LT treatment and cryopreservation in liquid nitrogen.

\begin{tabular}{lccc}
\hline \hline Source of variation & Sum of squares & df & Mean square \\
\hline Cold treatment & 369.8 & 2 & $184.9^{*}$ \\
ABA concentration & 1067.6 & 4 & $266.9^{* *}$ \\
Cold treatment $\times$ ABA concentration & 2599.2 & 6 & $433.2^{\text {** }}$ \\
Residual & 1785.6 & 32 & 55.8 \\
Total & 5822.2 & 44 & \\
\hline
\end{tabular}

,***Significant $\mathrm{F}$ test at $P \leq 0.05$ and $P \leq 0.01$.

on $2 \%$ or $3 \%$. LT treatments significantly increased the cold hardiness of the pear shoots grown on all sucrose concentrations. There was an interaction between medium sucrose concentration and LT treatment. Shoots grown on $7 \%$ sucrose had significantly lower $\mathrm{LT}_{50} \mathrm{~s}$ after 2 weeks of LT than with 0 or 1 week of $\mathrm{LT}$, but the $\mathrm{LT}_{50} \mathrm{~s}$ were not significantly different from the $3 \%$ and $5 \%$ sucrose plus 2 weeks of LT treatments.

High sugar concentrations in plant tissues are strongly correlated with freezing tolerance and cold hardiness (Gusta et al., 1996; Dumet et al., 1993). We increased the concentration of sucrose in the pear pretreatment medium and significantly increased cold hardiness of non-acclimated shoots. High sucrose concentrations also enhanced the effect of LT treatments on cold hardiness (Table 3) and decreased shoot water content (Fig. 3A). Generally, moisture content correlates negatively with cold hardiness in plants (Caswell et al., 1986; Tanino et al., 1990b; Yelenosky and Guy, 1989). Palonen and Junttila (1999) demonstrated that sucrose in the culture medium increased the sugar content of raspberry shoots and is readily taken up by shoots without prior hydrolysis.

Water content and osmotic potential of sucrose and ABA-cultured shoots. Shoot mois- 


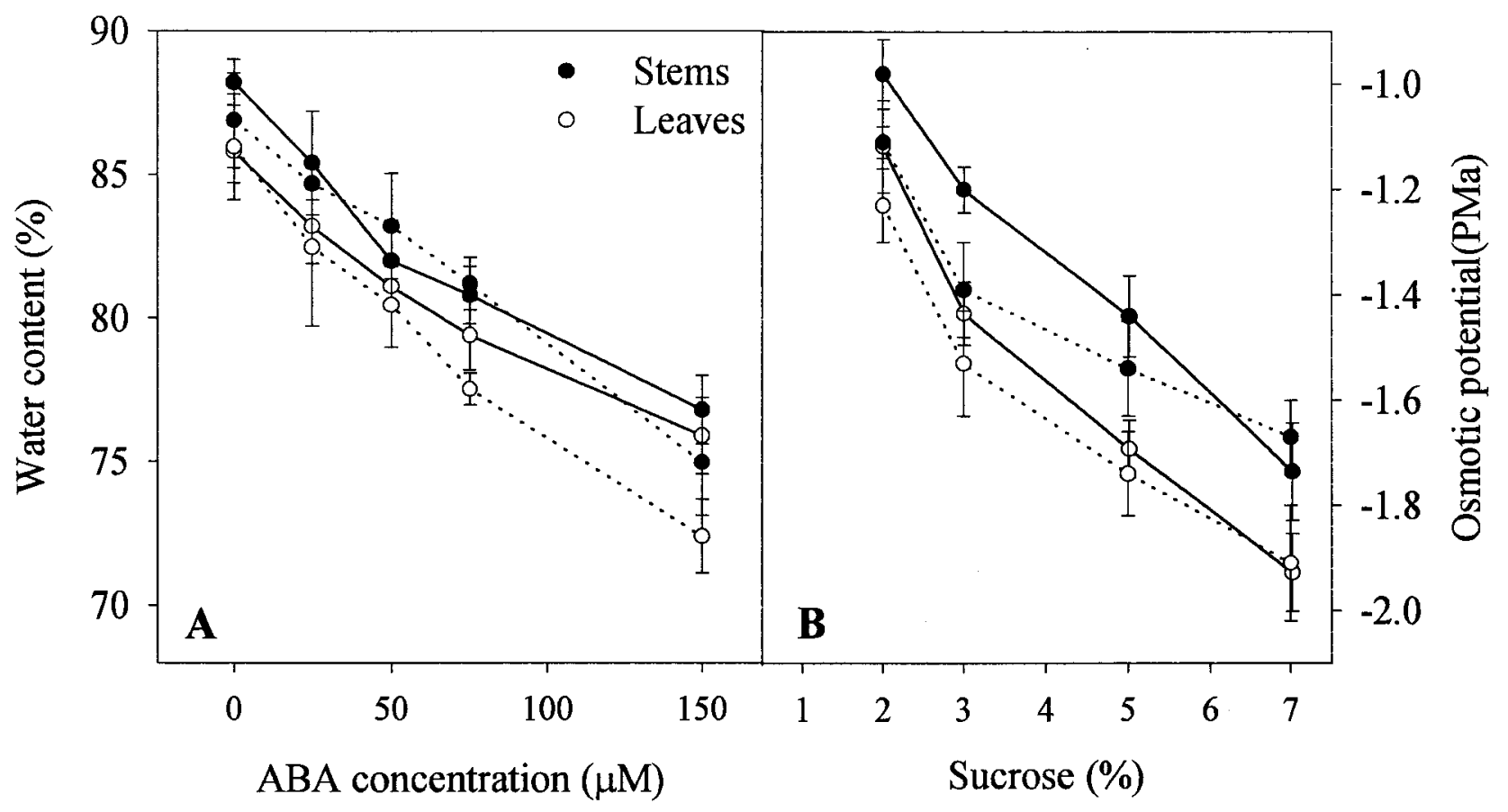

Fig. 3. Water content and osmotic potential of stems and leaves of $P$. cordata shoots following 3-week culture on Cheng medium with (A) five ABA concentrations or $(\mathbf{B})$ four sucrose concentrations. Shoots were grown at $25^{\circ} \mathrm{C}$ with a 16-h photoperiod. (dotted line) osmotic potential; (solid line) water content. $\mathrm{N}=60$; means $\pm \mathrm{SD}$.

ture content decreased from $86 \%$ to $71 \%$ for leaves and $89 \%$ to $75 \%$ for stems when the medium sucrose concentration increased from $2 \%$ to $7 \%$ (Fig. 3B). The osmotic potential of the shoots became more negative with the increased sucrose concentrations and the decline was similar to that for water content. Shoot water content decreased significantly, from $88 \%$ to $77 \%$ for stems, and $86 \%$ to $76 \%$ for leaves, after 3 weeks of ABA $(150 \mu \mathrm{M})$ treatment (Fig. 3A). The osmotic potential of ABA-treated tissues decreased with the increase in $\mathrm{ABA}$ concentration.

Effects of sucrose and BA on cryopreservation. Sucrose and BA in the preculture medium affected the growth of pear shoot tips following cryopreservation (Table 4). Shoots grown on $2 \%$ sucrose had poor recovery at all BA concentrations. Standard growth medium concentrations of BA $(4.44 \mu \mathrm{M})$ and sucrose $(3 \%)$ resulted in significantly less shoot tip growth than lower BA or higher sucrose concentrations. Growth of shoot tips following cryopreservation is influenced by the physiological condition of the parent shoots (Reed and Chang, 1997; Wu et al., 1999). Lower BA concentrations in the culture medium improved pear shoot growth (data not shown) and increased the growth of shoot tips following cryopreservation. High sucrose (5\% to $7 \%$ ) and BA $(2.22-4.44 \mu \mathrm{M})$ concentrations combined also produced good growth of cryopreserved shoot tips (Table 4).

LT treatments were the most effective pretreatments for increasing shoot cold hardiness and growth of cryopreserved pear shoot tips. Without LT treatment, ABA and sucrose in the culture medium decreased water content and osmotic potentials, but only slightly increased cold hardiness and tolerance to liquid nitrogen. ABA and sucrose effects

Table 3. Cold hardiness of in vitro-grown $P$. cordata shoots cultured 3 weeks on medium with $2 \%, 3 \%, 5 \%$, or $7 \%$ sucrose followed by 0,1 , or 2 weeks of LT pretreatment as determined by $\mathrm{LT}_{50}$.

\begin{tabular}{lllll}
\hline \hline & \multicolumn{4}{c}{$\left.\mathrm{LT}_{50}{ }^{\circ} \mathrm{C}\right)^{\mathrm{y}}$} \\
Sucrose $(\%)^{\mathrm{z}}$ & 0 & \multicolumn{4}{c}{$\mathrm{LT}$ duration $(\mathrm{wk})$} \\
\cline { 2 - 5 } & $-7.8 \mathrm{cB}$ & $-12.6 \mathrm{cA}$ & $-13.3 \mathrm{bA}$ & Means \\
\hline 2 & $-10.6 \mathrm{bC}$ & $-15.5 \mathrm{bB}$ & $-18.6 \mathrm{aA}$ & $-14.9 \mathrm{c}$ \\
5 & $-11.5 \mathrm{abC}$ & $-16.7 \mathrm{abB}$ & $-20.4 \mathrm{aA}$ & $-16.0 \mathrm{ab}$ \\
7 & $-12.4 \mathrm{aC}$ & $-17.5 \mathrm{aB}$ & $-20.3 \mathrm{aA}$ & $-16.7 \mathrm{a}$ \\
Means & $-10.5 \mathrm{C}$ & $-15.6 \mathrm{~B}$ & $-18.2 \mathrm{~A}$ & \\
\hline
\end{tabular}

${ }^{2}$ Shoots grown on $2 \%, 3 \%, 5 \%$, or $7 \%$ sucrose medium at $25^{\circ} \mathrm{C}$ for 3 weeks and then treated with 0,1 , or 2 weeks. LT treatments at $22^{\circ} \mathrm{C}$ with $8 \mathrm{~h}$ light $\left(10 \mu \mathrm{mol} \cdot \mathrm{m}^{-2} \cdot \mathrm{s}^{-1}\right)$ and $-1{ }^{\circ} \mathrm{C} 16 \mathrm{~h}$ darkness.

${ }^{\mathrm{y}}$ Means in a row with different capital letters (A-C) are significantly different at $P \leq 0.05$; Means in a column with different lower case letters $(\mathrm{a}-\mathrm{c})$ are significantly different at $P \leq 0.05$.

Table 4. Percentage of recovery of cryopreserved $P$. cordata shoot tips excised from shoots grown for 3 weeks on preculture medium with sucrose and BA and 2 weeks in combination with LT treatments.

\begin{tabular}{lcccc}
\hline \hline & \multicolumn{4}{c}{ Sucrose concentration $(\%)^{2}$} \\
\cline { 2 - 5 } BA concentration $(\mu \mathrm{M})$ & 2 & 3 & 5 & 7 \\
\hline 0.89 & $35 \pm 11.4 \mathrm{~b}$ & $60 \pm 15.8 \mathrm{a}$ & $70 \pm 7.8 \mathrm{a}$ & $58 \pm 12.3 \mathrm{a}$ \\
2.22 & $0 \mathrm{c}$ & $69 \pm 10.7 \mathrm{a}$ & $68 \pm 9.5 \mathrm{a}$ & $72 \pm 6.1 \mathrm{a}$ \\
4.44 & $0 \mathrm{c}$ & $25 \pm 8.9 \mathrm{~b}$ & $67 \pm 6.7 \mathrm{a}$ & $75 \pm 5.0 \mathrm{a}$ \\
\hline
\end{tabular}

${ }^{2}$ Shoots were precultured on Cheng medium with sucrose and BA for 3 weeks followed by LT treatment for 2 weeks $\left[22^{\circ} \mathrm{C}\right.$ with 8 -h light $\left(10 \mu \mathrm{mol} \cdot \mathrm{m}^{-2} \cdot \mathrm{s}^{-1}\right)$ and $-1{ }^{\circ} \mathrm{C} 16-\mathrm{h}$ darkness] $(\mathrm{n}=60)$. Means followed by different letters are significantly different at $P \leq 0.05$

were greatly enhanced when combined with LT treatment. Shoot tips and lateral buds were the most cold hardy ( -22.5 and -20.1$)$ with the combined LT-ABA treatment. The optimal shoot pretreatment for successful recovery of cryopreserved $P$. cordata shoot tips was a 3week culture on either $50 \mu \mathrm{M} \mathrm{ABA}$ or $5 \%$ to $7 \%$ sucrose medium followed by 2 weeks of LT, and increased shoot tip growth from 0 to $>70 \%$. This new procedure will increase the number of pear genotypes that can be successfully stored in liquid nitrogen.

\section{Literature Cited}

Anandarajah, K. and B.D. McKersie. 1990. Manipulating the desiccation tolerance and vigor of dry somatic embryos of Medicago sativa $\mathrm{L}$. with sucrose, heat shock and abscisic acid. Plant Cell Rpt. 9:451-455.

Caswell, K.L., N.J. Tyler, and C. Stushnoff. 1986. 
Cold hardening of in vitro apple and Saskatoon shoot cultures. HortScience 21:1207-1209.

Chang, Y. and B.M. Reed. 1997. The effects of in vitro-growth condition on the cryopreservation of Pyrus meristems. In Vitro Cell. Dev. Biol. 33:50A.

Chang, Y. and B.M. Reed. 2000. Extended alternating-temperature cold acclimation and culture duration improve pear shoot cryopreservation. Cryobiology 40: 311-322.

Chen, H.H., P.H. Li, and M.I. Brenner. 1983. Involvement of abscisic acid in potato cold acclimation. Plant Physiol. 73:71-75.

Chen, T.H.H. and L.V. Gusta. 1983. Abscisic acidinduced freezing resistance in cultured plant cells. Plant Physiol. 73:71-75.

Cheng, T.Y. 1979. Micropropagation of clonal fruit tree rootstocks. Compact Fruit Tree 12:127137.

Dallaire, S., M. Houde, Y. Gagne, H.S. Saini, S. Boileau, N. Chevrier, and F. Sarhan. 1994. ABA and low temperature induce freezing tolerance via distinct regulatory pathways in wheat. Plant Cell Physiol. 35:1-9.

Dumet, D., F. Engelmann, N. Chabrillange, Y. Duval, and J. Dereuddre. 1993. Importance of sucrose for the acquisition of tolerance to desiccation and cryopreservation of oil palm somatic embryos. Cryo-Letters 14:243-250.

Finkle, B.J. and J.M. Ulrich. 1979. Effects of cryoprotectants in combination on the survival of frozen sugarcane cells. Plant Physiol. 63:598604.

Guak, S. 1998. Water relations, stomatal conductance, and abscisic acid content of containergrown apple (Malus domestica) plants in response to sorbitol-induced osmotic stress. Ph.D. Dissertation, Oregon State Univ., Corvallis.

Gusta, L.V., R.W. Wilen, and P. Fu. 1996. Lowtemperature stress tolerance: The role of abscisic acid, sugars, and heat-stable proteins.
HortScience 31:39-45.

Lang, V., P. Heino, and E.T. Palva. 1989. Low temperature acclimation and treatment with exogenous abscisic acid induce common polypeptides in Arabidopsis thaliana (L.) Heynh. Theor. Appl. Genet. 77:729-734.

Lee, S.P., T.H.H. Chen, and L.H. Fuchigami. 1991. Changes in the translatable RNA population during abscisic acid induced freezing tolerance in bromegrass suspension culture. Plant Cell Physiol. 32:45-56.

Niino, T., A. Sakai, H. Yakuwa, and K. Nojiri. 1992. Cryopreservation of in vitro-grown shoot tips of apple and pear by vitrification. Plant Cell Tissue Organ Cult. 28:261-266.

Palonen, P. and O. Junttila. 1999. Cold hardening of raspberry plants in vitro is enhanced by increasing sucrose in the culture medium. Physiol. Plant. 106:386-392.

Pence, V.C. 1998. Cryopreservation of bryophytes: The effects of abscisic acid and encapsulation dehydration. Bryologist 101:278-281.

Reed, B.M. 1990. Survival of in vitro-grown apical meristems of Pyrus following cryopreservation. HortScience 25:111-113.

Reed, B.M. 1993. Responses to ABA and cold acclimation are genotype dependent for cryopreserved blackberry and raspberry meristems. Cryobiology 30:179-184.

Reed, B.M. and Y. Chang. 1997. Medium- and longterm storage of in vitro cultures of temperate fruit and nut crops, p. 67-105. In: M.K. Razdan and E.C. Cocking (eds.). Conservation of plant genetic resources in vitro, Vol. 1. Science Publishers, Inc., Enfield, NH.

Reed, B.M., J. DeNoma, J. Luo, Y. Chang, and L. Towill. 1998a. Cryopreservation and long-term storage of pear germplasm. In Vitro Cell. Dev. Biol.-Plant 34:256-260

Reed, B.M., C.L. Paynter, J. DeNoma, and Y.Chang. 1998b. Techniques for medium-and long-term storage of (Pyrus L.) genetic resources. Plant Gen. Res. Newsletter 115:1-4.

Rikin, A., C. Gitler, and C. Atsmon. 1981. Chilling injury in cotton: Light requirement for the reduction of injury and for the protective effect of abscisic acid. Plant Cell Physiol. 22:453-460.

Ryynanen, L. 1998. Effect of abscisic acid, cold hardening, and photoperiod on recovery of cryopreserved in vitro shoot tips of silver birch. Cryobiology 36:32-39.

Senaratna, T., L. Kou, W.D. Beversdorf, and B.D. McKersie. 1991. Desiccation of microspore derived embryos of oilseed rape (Brassica napus L.). Plant Cell Rpt. 10:342-344.

Tanino, K.K., T.H.H. Chen, L.H. Fuchigami, and C.J. Weiser. 1990a. Metabolic alterations associated with abscisic acid-induced frost hardiness in bromegrass suspension culture cells. Plant Cell Physiol. 31:505-511.

Tanino, K., C.J. Weiser, L.H. Fuchigami, and T.H.H. Chen. 1990b. Water content during abscisic acid induced freezing tolerance in bromegrass cells. Plant Physiol. 93:460-464.

Vandenbussche, B. and M.P. De Proft. 1998. Cryopreservation of in vitro sugar beet shoot tips using the encapsulation-dehydration technique: Influence of abscisic acid and cold acclimation. Plant Cell Rpt. 17:791-793.

Veisz, O., G. Galiba, and J. Sutka. 1996. Effect of abscisic acid on the cold hardiness of wheat. J. Plant Physiol. 149:439-443.

Withers, L.A. 1991. In-vitro conservation. Bio. J. Linnean Soc. 43:31-42.

Wu, Y., F. Engelmann, Y. Zhao, M. Zhou, and S. Chen. 1999. Cryopreservation of apple shoot tips: Importance of cryopreservation technique and of conditioning of donor plants. Cryo-Letters 20:121-130.

Yelenosky, G. and C. Guy. 1989. Freezing tolerance of citrus, spinach, and petunia leaf tissue. Plant Physiol. 89:444-451. 